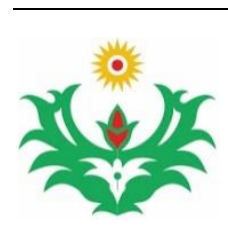

Linguistik Terapan 17 (1) (2020): 17-28

Jurnal Linguistik Terapan Pascasarjana

Available online

http://jurnal.unimed.ac.id/2020/index.php/JLT-Unimed

\title{
External and Internal Conjunctions in the News Story Text of the Jakarta Post
}

\author{
Novita Sari \\ Amrin Saragih \\ Anni Holila Pulungan \\ English Applied Linguistics Program \\ Postgraduate Program-Universitas Negeri Medan
}

Diterima Desember 2020; Disetujui Februari 2020; Dipublikasikan April 2020

\begin{abstract}
This study was investigated external and internal conjunctions in the news story text of the Jakarta Post based on Systemic Functional Linguistics Approach. The objective of this study was to describe the realization of external and internal conjunctions. The research was conducted by using qualitative design. The data of this research were clause complex of external and internal conjunctions in the news text the Jakarta Post. The data were taken from website official Jakarta Post https://www.thejakartapost.com/. The data were collected by documentary technique. The technique of data analysis applied interactive model technique by Miles, Huberman and Saldana (2014). The findings showed external and internal conjunctions describes in clause complex news text used to clause complex have several clauses consist of independent clause is an equal (paratactic) and clause complex have several clauses consist of independent clause relate with dependent clause is an unequal (hypotactic).
\end{abstract}

Keywords: External Conjunction, Internal Conjunctions, News Text

How to Cite: Sari, Novita (2020). External and Internal Conjunctions in the News Story Text of the Jakarta Post. Jurnal Linguistik Terapan Pascasarjana Unimed. 17 (1): 17-28

\section{ISSN 0216-5139}

\section{INTRODUCTION}

News is information about current events. News texts are articles or written interviews or recordings that inform the public about current events, concerns, or ideas. A news can be long or short, depending on the value of the news or its interest in people who listen to the radio, watch 
TV or read newspapers. News story text in newspaper can be found conjunctions. Conjunctions is very important in speech and writing.

Conjunctions is a part of speech that is used to connect words, phrases, clauses or sentences. In grammar conjunctions are coordinating conjunctions and subordinating conjunctions. But in the other side conjunctions not only to connect words, phrases or sentences and the types of conjunction not only coordinating and subordinating conjunctions. Conjunction as explained by Halliday and Hasan (1976) indicated that "conjunctive relations are not tied to any particular sequence in the expression". In other side conjunctions as a sets of meaning that organize activity sequences on the one hand, and text on the other.

Conjunction, as explained by Martin and Rose (2007) "conjunction looks at interconnections between processes-adding, comparing, sequencing, or explaining them. These are logical meanings that link activities and messages in sequences. "Describes conjunctions that are used to relate activities, as they construe a field beyond the text these are known as external conjunction and internal conjunction. External conjunctions express the relationship between external phenomena and internal conjunction shows the relationships inherent in the communication process. Halliday and Hasan (1976) described that are four types of conjunctions namely; additive, adversative, causal and temporal. Based on statement that the phenomena or form of conjunctive relations can be classified into four categories of conjunction.

Finally, this study was focused on external and internal conjunctions in the news story text of the Jakarta Post. These facts serve to be a motivation to conduct the present study dealing with external and internal conjunctions used in the text in order to find out what types of external and internal conjunctions used in the news text of the Jakarta Pos.

Conjunction is a word that functions to connect between two words, phrases, clauses or sentences. Conjunction, as explained by Bloor and Bloor (1995: 98) acts as "a cohesive bond between clauses or parts of the text in such a way as to show a meaningful pattern among them", although Halliday and Hasan (1976) show that "Conjunctive relationships not bound to a certain order in expression ". It shows several theories that relate the conjunctions between two clauses which is meaningful in one sentence and there is no relation of any particular sequences in the expression in conjunctions relation.

Halliday and Hasan (1976) uniquely suggest functional differences in conjunction namely: external and internal conjunctions. External conjunctions express the relationship 
between external phenomena and internal conjunction shows the relationships inherent in the communication process. Halliday and Hasan (1976) described that are four types of conjunctions namely; additive, adversative, causal and temporal. Based on statement that the phenomena or form of conjunctive relations can be classified into four categories that may occur in either external and internal conjunctions.

Conjunctions has been explained by Martin and Rose (2007) "conjunction looks at interconnections between processes adding, comparing, sequencing, or explaining them. These are logical meanings that link activities and messages in sequences." Describes conjunctions that are used to relate activities, as they construe a field beyond the text these are known as external conjunction and internal conjunction. connection of a clause with the preceding text.

Martin and Rose (2007) explained external and internal conjunctions realized in paratactic and hypotactic sequences in clause complex. Each clause is potentially independent, the dependency relation between them is an equal one. An equal dependency relation between two independent clauses is known as paratactic. An unequal dependency relation between a dependent clause and an independent clause is known as hypotactic. Halliday (1985:198) states that hypotactic is the binding elements of unequal status.

Paratactic is the same dependency relationship between two independent clauses. Paratactic itself was known as the each of the clauses relate with certain conjunctions could stand independently. Each clause is potentially independent, the dependency relationship between them were an equal one.

Hypotactic is the same dependency relationship between dependent clauses and independent clauses. Hypotactic itself is known as the each of the clauses related with certain conjunctions in order to stand dependent. One is independent, and the other beginning with certain conjunctions is dependent on it.

Halliday \& Hasan (1976) explained text is a linguistic unit that is functional in context. This text is called discourse in linguistics to indicate to every section, which is pronounced or written in any length, which forms tenors, fields and modes. Field, tenor and mode belong to the genre. Genres can be spoken or written. Text is not only used in grammar units but also in semantic units. In grammatical units such as clauses or sentences, text is sometimes considered a super-sentence. This means that it is related to sentences, clauses, phrases, or a group of words and so on. 
In the same page, Halliday \& Hasan specifies text as every part, pronounced or written in any length that forms a complete whole or the smallest part of meaningful social language. Text can also be defined as the use of actual language produced for communicative purposes. Furthermore, Macken (1991) explained text is a way of talking about any meaningful piece of language, which is made coherent by the social context in which it is produced.

A text can also be defined as any meaningful stretch of spoken or written language. It means when we use language to write, we are creating a text. When we read, we are interpreting texts and when we talk and listen, we are also creating and interpreting texts. Text and context are two language points that cannot be separated from each other as a system to convey meaning. Furthermore, Martin states that the text is best regarded as a semantic unit, Martin $(1992 ; 35)$. This does not only talk about the type or form of text but also the meaning of text that is functionally related to phrases, clauses, sentences and also other symbolic or contextual coding systems. So, that is to say why a text can be found between parts of a sentence or clause.

The meaning of the text must be understood in relation to its context such as the context of the situation and cultural context. The context of the situation refers to the immediate environment and where the text is produced, while the cultural context refers to the belief system, the values and attitudes that the speaker brings to any social interaction. Both the context of the situation and cultural context, the text influences the meaning of the text.

Fuller (1996) explained news is a report of what a news organization has recently learned about matters of some significance or interest to the specific community that news organization serves. A news story is a factual, prose story for print or broadcast media about a person, place or event answering these five questions: who, when, where, why and how (Cotter, 2012). A news story is written in the inverted pyramid style, giving the most important information first and additional details later.

News texts is texts that contain things about events that occur in the world which are then disseminated through media such as television, internet, websites, radio and other media. The purpose of the news text is to convey to readers, listeners and others about important information. So that do not miss information about events or so we know the latest information reported directly.

The Jakarta Post one of the newspaper name in Indonesia. Newspaper is one of media which provides a lot of news towards the recent issue in human's life. Garret (2006) stated 
newspaper were designed to provide information for a wide range of readers. Published daily or weekly, newspaper has some features such as news stories locally, nationally, and internationally, advertisement, opinion, entertainments, and editorials. Collins dictionary explained news is information that is published in newspaper and broadcast on radio and television about recent events in the country or world or in a particular area of activity. Oxford dictionaries stated news is newly received or noteworthy information, especially about recent events. Emery (1986) stated that newspaper as a means of communication, brings some important roles; they are to inform its readers objectively about what is happening in their community, country, and world.

In this book, Nunan (1993: 9) shares about Halliday (1985) arguing that written language is used for actions (for example, public signs, product labels, television and radio guides, bills, menus, telephone directories, ballots, computers manual); for example information, newspapers, the latest news magazines, advertisements, political pamphlets); and for entertainment (for example, comics, fiction books, poetry and drama, newspaper features, subtitle films). Discourse analysis also examines how the range of languages, considered in textual, social, and psychological contexts, becomes meaningful and united to its users (Cook, 1989). The aim is to avoid misunderstandings or misinterpretations between speakers and listeners in terms of communication.

Halliday (1975: 7), founder of the Systemic Functional Linguistic idea, said: "Linguistics is not and will never be an overall analysis of literature, and only literary analysts - not linguists can determine the place of linguistics in literature. studies. But if a text must be described at all, it must be explained correctly; and this means by theories and methods developed in linguistics, the subject of which is the right task to show how language works ".

\section{METHODOLOGY}

This study was conducted by using descriptive qualitative content analysis. The data are collected in the form of clause complex in the news text. Qualitative means to find out how a theory works in different phenomena. So, in this study to find out how the theory of external and internal conjunctions is used in the news story text of the Jakarta Post. This research is designed with single case system where it is conducted only in the news story text the Jakarta Post. 
The data of this study were clause complex of external and internal conjunctions in the news story texts of the Jakarta Post. The sources of the data in this study is the website official Jakarta Post https://www.thejakartapost.com/, as one of English written newspaper published in Indonesia. Strydom (1997, quoted in De Vos, 2005:31) argues that mass media can be viewed as excellent sources of information for researcher or producer to focus on factual. So, the news provided factual in form of the news text.

This study used a purposive sampling. Purposive sampling is a technique to determine the sample by certain consideration and the technique is appropriate to qualitative research (Sugiyono, 2008:218-219). By using this sampling, twelve news took from the Jakarta Post news paper, which is easily reachable for internet users in its official website https://www.thejakartapost.com/. These selected the news bring out some background reasons.

1. These twelve selected news text were taken as an adequate number for data analysis. By using referential adequacy, the portion number of the news are enough selected since the reoccurrence happened regularly during the data analysis. They also represented as they were suitable as a representative number of publication in year.

2. Six news from each month, which were as representative of the first week of the month, represented the different issues from August till September 2019.

Since the Jakarta Post is not providing any news on Sunday, so there are six selected news took in the first week of the month. Patton (2002:4) stated that qualitative findings grow out of three kinds of data collection: (1) in-depth, open-ended interviews, (2) direct observation and (3) written documents. However, this study only took written document, since it concerned in the news text newspaper. Since this study were conducted by using qualitative research, the research acts the key of instrument. Hence, the instrument was suitable used to collect the data were documentary. Therefore, documentary technique was conducted.

The data analysis is process systematically searching and arranging the interview, transcript, field's notes and other materials that the writer accumulate to increase the understanding of them and to enable the writer to present what he has discovered to other (Bogdan and Biklen: 1982). The purpose of data analysis is summarizing and simplifying the data in order to interpret and draw a conclusion.

The data was analysed by using interactive models by Huberman\& Saldana [11] the steps are data condensation, data display, and data drawing/verification. 


\section{Data Condensation}

The condensation refers to the processes of selecting, focusing, simplifying, abstracting and transforming.

a. Selecting: In this process, the way to choose the best or most suitable data based on the research needed. The data were selected on the criteria of external and internal conjunctions used

b. Focusing: In this process, the researcher will only focus on external and internal conjunctions used in the news text.

c. Simplifying: In this process, simplifying by categorizing the written text into types of external and internal conjunctions in the news text in order to make them easier to be classified.

d. Abstracting: In this process of making written summary the data related to types of external and internal conjunctions used by analysis in the news story text of the Jakarta Post.

e. Transforming: In this step, the researcher displays the data into written summary.

\section{Data Display}

Data display is where the researcher analyzed the clause complex in the text by using external and internal conjunction types with table.

\section{Drawing and Verifying Conclusion}

Drawing and Verifying Conclusion will draw or verify base on the data analysis. The conclusion in qualitative research is a new discovery that can be an answer of the research problem. The conclusion is in the form of description of the object of this study. Finally, in this step the researcher will get the result and conclusion of the research. Step in analyzing data in this research are: 1). the researcher will collect the data through interview, observation and documentation. Then, researcher will select by referring to formulation of the research problems in the study, 2). After collecting and reducing the data, the researcher will display those transcript data in the form of narrative. Finally, in this step the researcher can get the result and conclusion of the research in the form description of the subject of this study.

In this step, after selecting the clause complex of news text which contains external and internal conjunctions, the researcher makes the texts into table. In conclusion drawing, the researcher concludes what types of external and internal conjunctions used in the news text of the Jakarta Post. The trustworthiness of the study is based on the model by Lincoln \&Guba [6] in 
which credibility, transferability, dependability, and conformability are established in collecting and analyzing data.
1. Credibility
3. Dependability
2. Transferability
4. Confirmability

\section{FINDING AND DISCUSSION}

After analyzing the data, the data are classified the realization of external and internal conjunctions used. In described the data of external and internal conjunctions. External and internal conjunctions are used in the news story text of the Jakarta Post after having analyzed.

Table 1.Realization of External and Internal Conjunctions

\begin{tabular}{cccc}
\hline No & $\begin{array}{c}\text { Realization of External } \\
\text { and Internal } \\
\text { Conjunctions }\end{array}$ & Total & $\%$ \\
\hline 1 & Paratactic & 57 & $71 \%$ \\
2 & Hypotactic & 23 & $29 \%$ \\
\hline & Total & $\mathbf{8 0}$ & $\mathbf{1 0 0} \%$ \\
\hline
\end{tabular}

Based on the Table 1, the logical relation strongly holds the major influencing in case of meaning. In this case, all news story texts were realized by external and internal conjunctions in part of their adapting the logical meaning in a one clause with the other clauses in clause complex in news story text of the Jakarta Post. External and internal conjunctions realized in the news text were paratactic sequence and hypotactic relation.

Paratactic itself is each clause is potentially independent, the dependency relationship between them were an equal one.

\section{Relationship between an Equal One}

Most of the other steps were not new, such as pushing infrastructure development to increase logistic efficiency, easing licensing procedures through the Online Single Submission (OSS) system and creating a more conducive regulatory environment through tax incentives, said 
Coordinating Economic Minister Darmin Nasution. (JP: Government wants to revive manufacturing to spur growth, September 6th, 2019).

Based on the data, it shows that the clause complex was paratactic sequence. There was conjunction and, it is part of 'external addition'. The realization of conjunction and in the clause complex it was meaning was addition. Used the conjunction and to add clause in paratactic sequence. Each clause were independent clause, then relate with conjunction and to add another independent clauses.

\section{Relationship between an equal one}

The President, who is slated to visit Malaysia and Singapore this week, called on regional administrations, Indonesian Military (TNI), National Police, National Disaster Mitigation Agency (BNPB) and Peatland Restoration Agency (BRG) to work together cooperatively. (JP: Jokowi warns on danger of hotspots as dry season hits, August 7th, 2019).

Based on the data, it shows that the clause complex was paratactic sequence. There were conjunctions and, it is part of 'external addition'. The realization of conjunction and in the clause complex it was meaning addition. Used the conjunction and to add clause in paratactic sequence. Each clause were independent clause, then relate with conjunction and to add another independent clauses.

\section{Relationship between an equal one}

Ignatius said the hackers not only stole names and email addresses, but also consumers' credit card data and information related to bank accounts. (JP: Cyberattacks, fraud threaten digital economy, September 5th, 2019).

Based on the data, it shows that the clause complex was paratactic sequence. There were conjunctions and, but it is part of 'external addition'. The realization of conjunction and, but in the clause complex its meaning was addition. Used the conjunction and, but to add clause in paratactic sequence. Each clause were independent clause, then relate with conjunction and, but to add another independent clauses.

Hypotactic itself is known as the each of the clauses related with certain conjunctions in order to stand dependent. One is independent, and the other beginning with certain conjunctions is dependent on it. 


\section{Relationship between an unequal one}

The global economy was still colored with uncertainties, while commodity prices also fluctuated. (JP: Inflation rose in August to highest level since December 2017, September 2nd, 2019).

Based on the data, it shows that the clause complex was hypotactic sequence. There were conjunction while, it is part of 'external time. The realization of conjunction while its meaning time. Used conjunction while to relate the clauses at events happen. One clause is independent, then the other beginning with while is dependent on it. Conjunction "while" clause functions as the context in which the other takes place. In this respect its function is similar to a circumstance of time such as after commodity prices also fluctuated the global economy was still colored with uncertainties, which can come at the start or end the clause.

\section{Relationship between an unequal one}

Reviving Indonesia's manufacturing sector by boosting exports was crucial to achieve higher economic growth, which has been overshadowed by current account deficit pressure from the trade deficit, said BI Deputy Governor Dody Budi Waluyo. (JP: Government wants to revive manufacturing to spur growth, September 6th, 2019)

Based on the data, it shows that the clause complex was hypotactic sequence.There is conjunctions by, it is part of 'external consequence'. The realization of conjunction by its meaning means. Used the conjunction by to clarify why an effect happens, the correlation of means explains how something happens in hypotactic relations.

\section{Relationship between an unequal one}

According to Henri, the price of roaster machines can range from Rp 8 million to Rp 1 billion. Henri suggests that people do a trial run in the coasting space and learn how to roast coffee properly before investing in a machine. (JP: Coffee roasters thrive caffeine craze sweeps capital, September 4th, 2019).

Based on the data, it shows that the clause complex was hypotactic sequence. There was conjunction before, it is part of 'external time. The realization of conjunction before its meaning time. Used the conjunction before to relate the clauses at events happen. Two clauses is independent, then the other beginning with before is dependent on it. In this respect its function 
was similar to a circumstance of time such as after investing in a machine that people do a trial run in the coroasting space and learn how to roast coffee properly.

\section{CONCLUSION}

Conjunctions could be find in the new story on the newspaper. In grammar conjunctions are coordinating conjunctions and subordinating conjunctions. But in the other side conjunctions not only to connect words, phrases or sentences and the types of conjunction not only coordinating and subordinating conjunctions. These are logical meanings that link activities and messages in sequences." Describes conjunctions that are used to relate activities, as they construe a field beyond the text these are known as external conjunction and internal conjunction. External and internal conjunctions had studied in discourse analysis subject. Explained external and internal conjunctions is looked from has been learned. It is seen from what has been learned. The conjunctions on newspaper divided into two types of sequences are paratactic and hypotactic sequence.

\section{REFERENCES}

Bloor, Thomas \& Bloor, Meriel. 1995. The Functional Analysis of English. USA: Oxford University.

Bogdan and Biklen. 1982. Qualitative Research in Education, an Introduction to Theory and Method. Bostom: Allyn \& Bacon.

Halliday,M.A.K and Hassan Ruqaiya. 1976. Cohesion in English. London: Longman Inc.

Halliday, M. A. K. \& Hasan, R. 1985. Language, Context, and Text: Aspects of Language in Social Semiotic Perspective. Geelong, Vic: Deakin University Press.

Halliday, M. A. K. 2004. An Introduction to Functional Grammar. Third Edition. Hodder Arnlod. University of Sydney. Australia.

Lincoln, Y. S., \& Guba, E, G. 1985. Naturalistic Inquiry. New Bury Park, CA: Sage Publications

Martin J.R \& Rose, David. 2007. Working with Discourse Meaning beyond the Clause. London: Continuum.

McCarthy, M. 1993. Discourse Analysis. Cambridge: Cambridge University Press.

Miles, M., M Huberman, J. Saldana. 2014. Qualitative Data Analysis, a Methods Sourcebook. Amerika: Arizona State University. 
Nunan, David. 1993. Introducing Discourse Analysis. London: Penguin English.

Oxford Advanced Learner's Dictionary, New York: Oxford University Press.

Patton, M. Q and Cochran, M. 2002. A Guide to Using Qualitative Research Methodology.

https://www.collinsdictionary.com/amp/english/news

https://en.oxforddictionaries.com/defenition/news

https://www.thejakartapost.com 